\title{
GAMBARAN TINGKAT ANSIETAS SUAMI ATAU ISTRI YANG DITINGGAL PASANGANNYA BEKERJA DILUAR NEGERI
}

\author{
Livana PH ${ }^{1}$, Nur Fatoni ${ }^{1}$, Mohammad Fatkhul Mubin \\ ${ }^{1}$ Program Studi Ners STIKES Kendal \\ ${ }^{2}$ FIKKes Universitas Muhammadiyah Semarang \\ livana.ph@gmail.com
}

\begin{abstract}
ABSTRAK
Ansietas merupakan respon emosional terhadap penelitian individu yang subjektif, yang dipengaruhi alam bawah sadar dan tidak diketahui secara khusus penyebabnya. Ansietas merupakan reaksi emosional terhadap persepsi adanya bahaya, baik yang nyata maupun yang hanya dibayangkan. Ansietas yang dirasakan pada pasangannya yang ditinggal keluar negeri yaitu Ansietas ringan sampai berat yang dialami oleh semua orang. Tujuan dalam penelitian ini adalah mengetahui gambaran tingkat Ansietas pada suami atau istri yang ditinggal pasangannya bekerja diluar negeri di desa Tambaksari Kecamatan Rowosari Kabupaten Kendal. Metode penelitian ini adalah deskriptif eksploratif. Populasi penelitian ini adalah suami atau istri yang ditinggal pasangnnya bekerja keluar negeri dengan ukuran sampel 54 orang. Teknik sampel dalam penelitian ini adalah Simpel random sampling. Data dianalisis dengan sentral tendensi dan distribusi frekuensi. Hasil penelitian menunjukan bahwa mayoritas responden mengalami ansietas sedang sebanyak 33 responden $(61,1 \%)$. Saran diharapkan masyarakat tidak terlalu Ansietas karena memikirkan suami atau istri yang bekerja keluar negeri, sehingga bisa bekerja dirumah untuk membantu suami/istri yang bekerja diluar negeri dan diharapakn bisa menjalin komunikasi yang baik antara suami dan istri
\end{abstract}

Kata kunci: Ansietas, suami atau istri, bekerja keluar negeri

\section{DESCRIPTION OF THE HUSBAND ANSIETAS OR WIFE LETED BY THE COUPLE WORKING OUTSIDE THE STATE}

\begin{abstract}
Anxiety is an emotional response to individual research that is subjective, which is influenced by the subconscious and is not specifically known for the cause. Anxiety is an emotional reaction to the perception of danger, both real and imagined. Anxiety is felt in the partner who is left out of the country namely mild to severe anxiety experienced by everyone. The purpose of this research is to describe the level of anxiety in the husband or wife who left their spouse working abroad in the village of Tambaksari, Rowosari Subdistrict, Kendal Regency. This research method is descriptive explorative. The population of this study was the husband or wife who were left behind and worked abroad with a sample size of 54 people. The sample technique in this study is Simple random sampling. Data were analyzed by central tendency and frequency distribution. The results showed that the majority of respondents experienced moderate anxiety as many as 33 respondents (61.1\%). The suggestion is that the community is not too anxious because they think of a husband or wife who works abroad, so they can work at home to help their spouse who works abroad and is expected to establish good communication between husband and wife
\end{abstract}

Keywords: Anxiety, husband or wife, working abroad

\section{PENDAHULUAN}

Krisis moneter yang melanda Indonesia tahun 1997 meningkatkan angka kemiskinan dan angka pengangguran. Jumlah penduduk miskin selama periode 1996-2006 berfluktuasi dari tahun ke tahun, yaitu 34.01 juta jiwa pada tahun 1996 menjadi 39.05 juta jiwa pada tahun 2006 (BPS 2006). Begitu pula angka pengangguran terbuka meningkat tajam dari
4.280 orang pada tahun 1997 menjadi 10.93 juta orang pada tahun 2006 (Antara, 2007).

Dalam program rencana pembangunan jangka panjang menengah 2004-2009, pemerintah menargetkan peningkatan pengiriman TKI dari hampir 700.000 orang pada tahun 2006 menjadi 1 juta orang pertahun hingga tahun 2009. Demikian pula target negara tujuan akan 
diperluas dari 11 negara menjadi 25 Negara (Subkhan, 2007).

Pada tahun 2011 jumlah tenaga kerja Indonesia yang bekerja di luar negeri yang berasal dari kota Semarang sebanyak 3.799 jiwa. Di daerah Kabupaten Kendal jumlah tenaga kerja Indonesia yang bekerja ke luar negeri sebanyak 14.022 jiwa. Masalah-masalah yang terjadi pada TKI yang bekerja keluar negeri seperti kekurangan gaji, kematian TKI, TKI sakit, pemulangan TKI karena salah dalam bekerja, pemutusan hubungan kerja, penipuan yang dilakukan oleh CTKI (PWNI/BHI Kemlu, 2012).

Jumlah kasus WNI/TKI bermasalah yang telah ditangani oleh Perwakilan RI dan Kementerian Luar Negeri RI pada tahun 2010, khusus untuk kawasan Asia dan Timur Tengah adalah sebanyak 15.766 kasus, masing-masing sebanyak 5.179 kasus di Asia dan 10.587 kasus di Timur Tengah. Dari sejumlah 3.113 kasus yang ada di Asia, sebanyak 2.953 kasus (95\%) sudah diselesaikan, dan sebanyak 160 kasus (5\%) masih dalam proses penyelesaian. Sementara di Malaysia, dari 2.066 kasus yang ada, sebanyak 1.779 (86\%) sudah diselesaikan dan yang masih dalam proses penyelesaian sebanyak 287 kasus (14\%). Kasus-kasus yang telah diselesaikan pada umumnya dibagi dalam tiga jenis kasus, yaitu kasus repatriasi, meninggal dunia dan kasus-kasus lainnya, seperti kembali lagi ke majikan awal, pindah ke majikan lain, dan dikirim ke kantor polisi untuk di deportasi (khususnya di wilayah Timur Tengah). Kasus repatriasi yang telah diselesaikan sebanyak 6.287 kasus atau 44\%, meninggal dunia sebanyak 1.297 kasus atau 9\%, dan kasus lain-lain sebanyak 6.784 atau 47\% (PWNI/BHI Kemlu, 2012).

Jumlah WNI/TKI yang meninggal dunia di luar negeri karena kecelakaan kerja sepanjang 2009-2010 adalah sebanyak 1.297 orang. Sebagian, yaitu sebanyak 882 jiwa (68\%) dimakamkan di luar negeri, sementara sebagian lagi, yaitu sebanyak 415 jiwa (32\%), dimakamkan di dalam negeri. Kasus repatriasi dan deportasi terhadap WNI/TKI di luar negeri sepanjang Januari hingga Desember 2010, adalah sebanyak 6.287 kasus repatriasi dan 2.872 kasus deportasi. Jika dilihat berdasarkan kawasan, maka kasus repatriasi yang terjadi di Timur Tengah (minus Arab Saudi), berjumlah 1.397 kasus atau 22\%. Sementara yang terjadi di Arab Saudi sebanyak 1.236 kasus atau 20\%, dan di Malaysia sebanyak 3.322 kasus atau $53 \%$, dan di kawasan lainnya sejumlah 332 kasus atau 5\%. Sementara untuk kasus deportasi berdasarkan kawasan sepanjang tahun 2010, di Malaysia sebanyak 15.021 kasus atau 51\%, di Arab Saudi sebanyak 13.660 atau $48 \%$, dan di kawasan lainnya sebanyak 40 kasus atau $1 \%$, masalah tersebut menyebabkan pasangan yang ditinggalkan merasa Ansietas (PWNI/BHI Kemlu, 2012).

Ansietas merupakan respon emosional terhadap penelitian individu yang subjektif, yang dipengaruhi alam bawah sadar dan tidak diketahui secara khusus penyebabnya (Dalami, 2009). Menurut Smeltzer (2001), Ansietas merupakan reaksi emosional terhadap persepsi adanya bahaya, baik yang nyata maupun yang hanya dibayangkan. Ansietas yang dirasakan pada pasangannya yang ditinggal keluar negeri yaitu Ansietas ringan sampai berat yang dialami oleh semua orang.

Gangguan Ansietas merupakan Ansietas dan kekhawatiran yang tidak real pada suami atau istri yang terjadi karena perpisahan dengan orang-orang yang berperan penting dalam hidupnya. Misalnya, ketakutan itu mungkin berpusat pada apa yang mungkin terjadi dengan individu yang berpisah dengan suami atau istri yang ditinggalkan selama bekerja diluar negeri (misalnya, takut jika diluar negeri meninggal, disana menikah lagi, atau tidak kembali karena suatu alasan) sehingga muncul Ansietas pada pasangan yang ditinggalkan (Smeltzer, 2001).

Ansietas yang dialami oleh pasangan suami atau istri menyebabkan mereka tidak bisa konsentrasi, mengalami gangguan tidur, mudah marah, merasa tertekan, gelisah, mudah lelah, terkejut dan merasa takut. Studi pendahuluan yang dilakukan peneliti pada tanggal 27 Oktober 2012 kepada 5 reponden yang suami atau istri bekerja ke luar negeri, 3 diantaranya mengatakan Ansietas karena pasangannya bekerja keluar negeri sedangkan 2 diantaranya tidak Ansietas karena pasangannya bekerja keluar negeri untuk bekerja, menghasilkan uang dan meningkatkan ekonomi rumah tangga.

\section{METODE}

Jenis penelitian ini adalah deskriptif dengan desain deskriptif eksplorasi. Populasi atau situasi sosial dalam penelitian ini adalah suami atau istri yang ditinggal pasangnnya bekerja 
keluar negeri yang berjumlah 116 orang. Sampel dalam penelitian ini adalah suami atau istri yang ditinggal pasangnnya bekerja keluar negeri di Desa Tambaksari Kecamatan Rowosari Kabupaten Kendal. Teknik sampling menggunakan Simpel random sampling. Besar sampel ditentukan dengan kriteria inklusi sebagai berikut: (1)Suami atau istri yang ditinggal pasangannya bekerja keluar negeri di Desa Tambaksari Kecamatan Rowosari Kabupaten Kendal. (2)Suami atau istri yang ditinggal pasangannya bekerja keluar negeri yang bersedia menjadi responden. Adapun kriteria eksklusi dalam penelitian adalah:
(1)Suami atau istri yang ditinggal pasangnnya bekerja keluar negeri di Desa Tambaksari Kecamatan Rowosari Kabupaten Kendal yang sedang sakit. (2)Suami atau istri yang ditinggal pasanganya bekerja keluar negeri di Desa Tambaksari Kecamatan Rowosari Kabupaten Kendal yang sedang dalam proses perceraian. Besar sampel dalam penelitian ini yaitu 54 orang. Data dianalisis secara univariat berupa central tendensi dan distribusi frekuensi.

\section{HASIL}

Hasil penelitian disajikan pada tabel berikut.

Tabel 1.

Karakteristik responden berdasarkan umur $(\mathrm{n}=54)$

\begin{tabular}{lccccccc}
\hline \multicolumn{1}{c}{ Umur } & $\mathrm{f}$ & $\%$ & Mean & Median & Modus & Standar deviasi & Nilai Min-max \\
\hline$<20$ tahun & 9 & 16,7 & & & & & \\
\hline $20-35$ tahun & 33 & 61,1 & 28,15 & 27 & 19 & 6,574 & $18-41$ \\
\hline$>35$ tahun & 12 & 22,2 & & & & & \\
\hline
\end{tabular}

Tabel 2.

Karakteristik responden $(n=54)$

\begin{tabular}{lcc}
\hline \multicolumn{1}{l}{ Karakteristik } & $\mathrm{f}$ & $\%$ \\
\hline Jenis kelamin & 34 & 63 \\
Laki-laki & 20 & 37 \\
Perempuan & & \\
Pendidikan & 5 & 9,3 \\
SD & 34 & 63,0 \\
SMP & 15 & 27,8 \\
SMA & & \\
Penghasilan & 16 & 33,3 \\
<UMR & 29 & 53,7 \\
= UMR & 7 & 13,0 \\
> UMR & & \\
\hline Kebutuhan & 27 & 50,0 \\
Kurang & 19 & 35,2 \\
Cukup & 8 & 14,8 \\
Lebih & & \\
\hline
\end{tabular}

Tabel 3.

Tingkat Ansietas responden $(n=54)$

\begin{tabular}{lcc}
\hline Tingkat Ansietas & $\mathrm{f}$ & $\%$ \\
\hline Ringan & 16 & 29,6 \\
\hline Sedang & 33 & 61,1 \\
\hline Berat & 5 & 9,3 \\
\hline
\end{tabular}

\section{PEMBAHASAN}

\section{Karakteristik responden}

1. Umur

Hasil penelitian menunjukan bahwa mayoritas responden di Desa Tambaksari berumur 20-35 tahun sebanyak 33 responden $(61,1 \%)$. dan rata-rata pasangan responden berumur dewasa muda sehingga pasangan responden cukup mudah untuk bekerja keluar negeri karena umur juga menjadi salah satu persyaratan untuk dapat bekerja keluar negeri. Hasil penelitian sesuai dengan teori Nursalam (2001) yang mengatakan bahwa semakin cukup umur tingkat kematangan dan kekuatan seseorang 
akan lebih matang dalam berfikir dan bekerja dari segi kepercayaan masyarakat yang lebih dewasa akan lebih percaya dari pada orang belum cukup kedewasaannya. Penelitian yang dilakukan Setyawan (2008) tentang analisis faktor-faktor yang berhubungan dengan tingkat Ansietas pasien pre-operasi diruang perawatan bedah Rumah Sakit Umum Haji Makassar didapatkan hasil bahwa terdapat hubungan antara usia dengan Ansietas dengan nilai $\mathrm{p}=0,014$.

\section{Jenis kelamin}

Hasil penelitian menunjukan bahwa mayoritas responden berjenis kelamin laki-laki sebanyak 34 responden $(63,0 \%)$. Hal ini dikarenakan banyak pasangan responden yang berjenis kelamin perempuan yang bekerja keluar negeri, tenaga kerja Indonesia yang bekerja keluar negeri umumnya bekerja sebagai pembantu rumah tangga, sehingga kebanyakan responden yangpeneliti dapatkan berjenis kelamin laki-laki. Perempuan mempunyai sifat keterbukaan, seperti lebih banyak mengungkapkan keadaan dirinya dan sesuatu yang dirasakan, serta tentang Ansietas atau rasa tertekannya. Sedangkan laki-laki cenderung diam, tidak terbuka sehingga jika mempunyai masalah sering dipendam sendiri (Yumana dan Maramis, 2002).

\section{Pendidikan}

Hasil penelitian menunjukan bahwa mayoritas responden berpendidikan SMP sebanyak 34 responden (63,0\%). Menurut Suwarno (1991) yang dikutip Nursalam (2001). Pendidikan adalah bimbingan yang diberikan oleh seseorang terhadap perkembangan orang lain menuju kearah cita-cita tertentu. Pendidikan itu menuntut manusia untuk berbuat dan mengisi kehidupannya untuk mencapai keselamatan dan kebahagiaan. Hasil wawancara dengan responden, banyak responden yang mengganggap pendidikan mereka dianggap tidak terlalu penting atau tidak terlalu diprioritaskan karena menurut responden lulusan SMP sudah bisa bekerja sehingga setelah lulus SMP tidak perlu meneruskan pendidikan ke jenjang lebih tinggi

Hasil penelitian ini tidak sesuai dengan teori Notoatmodjo (2005) yang menyatakan bahwa pendidikan seseorang merupakan salah satu proses perubahan tingkah laku, semakin tinggi pendidikan seseorang maka dalam memilih pekerjaan bisa diperhitungkan. Pendidikan adalah proses pengubahan sikap dan tatalaku seseorang atau kelompok orang dalam usaha mendewasakan manusia melalui upaya pengajaran dan pelatihan, proses, cara, perbuatan mendidik (Pusat Bahasa Departemen Pendidikan Nasional, 2002).

\section{Penghasilan}

Hasil penelitian menunjukan bahwa mayoritas responden berpenghasilan sama dengan UMR Kabupaten Kendal (Rp. 904.500) sebanyak 29 responden $(53,7 \%)$. Penghasilan tersebut didapatkan dari jualan hasil dari pertanian, jual ikan yang ada ditambak dan penghasilan dari istri yang bekerja keluar negeri. Salah satu harapan dengan bekerja keluar negeri penghasilan bertambah dan kebutuhan bisa terpenuhi karena menjadi petani atau peternak ikan saja tidak cukup untuk memenuhi kebutuhan sehari dalam rumah tangga (Notoatmodjo, 2003).

Hasil penelitian ini sesuai dengan teori Nursalam (2001) yang mengatakan bahwa pekerjaan merupakan aktivitas utama yang dilakukan oleh manusia. Pekerjaan digunakan untuk suatu tugas atau kerja yang menghasilkan uang bagi seseorang.

\section{Tingkat Ansietas pada suami atau istri yang} ditinggal pasangannya bekerja diluar negeri Hasil penelitian menunjukan bahwa mayoritas responden mengalami Ansietas sedang sebanyak 33 responden $(61,1 \%)$. Hal ini dikarenakan karena banyak masalah yang dihadapi dalam bekerja diluar negeri. Hasil wawancara dengan responden mengatakan bahwa masalah yang sering muncul pada istri yang bekerja keluar negeri antara lain: uang hasil bekerja habis karena ditipu orang lain, tidak pulang-pulang karena menikah dengan orang lain, sehingga suami atau istri yang ditinggal pasangnya akan merasa Ansietas dengan kondisi yang seperti itu.

Responden mengalami Ansietas sedang ini dikarenakan adanya perpisahan. Perpisahan terjadi ketika seseorang harus di beri jarak dengan yang disayangi, suami atau istri yang bekerja keluar negeri harus mengorbankan perasaannya demi kebutuhan ekonomi yang harus tercukupi, baik kebutuhan anak, kebutuhan sehari-hari maupun kebutuhan yang tidak terduga. Masalah-masalah yang terjadi pada tenaga kerja Indonesia yang bekerja keluar negeri seperti kekurangan gaji, kematian tenaga kerja Indonesia, tenaga kerja Indonesia yang sakit, pemulangan tenaga kerja Indonesia 
karena salah dalam bekerja, pemutusan hubungan kerja, penipuan yang dilakukan oleh tenaga kerja Indonesia sehingga banyak responden yang mengalami Ansietas. Ansietas yang dirasakan responden berkaitan dengan perasaan yang tidak pasti dan tidak berdaya. Sehingga perasaan pasangannya yang ditinggal keluar negeri tidak karuan. Suami atau istri yang ditinggal pasangnya bekerja keluar negeri berharap agar suami atau istri yang bekerja diluar negeri diberikan kesuksesan, selalu diberi kesehatan dan pulang ke Indonesia dengan selamat dan mendapatkan ekonomi yang sesuai dengan harapan.

\section{SIMPULAN DAN SARAN \\ Simpulan}

Mayoritas responden berumur 20-35 tahun, berjenis kelamin laki-laki, berpendidikan SMP, berpenghasilan sama dengan UMR Kabupaten Kendal, dan rata-rata penghasilan responden untuk memenuhi kebutuhan sehari-hari mempunyai kebutuhan yang kurang. Mayoritas responden mengalami ansietas sedang

\section{Saran}

1. Masyarakat

Diharapkan suami atau istri yang ditinggal bekerja keluar negeri jika mengalami Ansietas melakukan mekanisme koping yang adaptif seperti berdo'a semoga suami atau istri yang bekerja keluar negeri diberikan kesehatan, kesuksesan dan pulang ke Indonesia dengan selamat.

2. Institusi

Diharapkan lebih banyak memfasilitasi dan menyediakan buku-buku yang berhubungan dengan penelitian khususnya tentang buku keperawatan jiwa dan menyediakan kurikulum pendidikan mengenai penyusunan skripsi.

3. Peneliti selanjutnya

Diharapkan dapat membuat atau melakukan penelitian tentang Ansietas dengan variabel yang berbeda dan dan menggunakan metode penelitian yang berbeda seperti penelitian kualitatif.

4. Perawat

Diharapkan perawat dapat memberikan pendidikan kesehatan tentang Ansietas, memberikan pendidikan kesehatan tentang mekanisme koping dalam menghadapi Ansietas dan cara mengatasi Ansietas.

\section{DAFTAR PUSTAKA}

Dalami, E. Dkk. (2009). Asuhan Keperawatan Jiwa dengan masalah psikososial. Jakarta : CV. Trans Info Media

Dian

(2004).

http://darsananursejiwa.blogspot.com/2

009/06/hubungan-peran-yangdilakukan. diakses 4 oktober 2012

Hawari, Dadang. (2009). Psikometri Alat Ukur (Skala) Kesehatan Jiwa. Jakarta : FKUI.

Lubis (2002), Metode Riset untuk Desain. Komunikasi Visual. Yogyakarta: Penerbit Andi

Niven (2003). Psikologi Kesehatan edisi kedua. Jakarta: EGC

Notoatmodjo, S. (2005) Metodologi Penelitian Kesehatan. Jakarta: PT Rineka Cipta.

PWNI/BHI Kemlu, (2012). Pemasalahan Sosial TKW dan Implikasinya terhadap Pelayanan Sosial. http://wikipedia, Ensiklopedia diakses 4 oktober 2012

Smelter, Suzanne C. (2001) Buku Ajar Keperawatan Bedah, Jakarta : EGC

Stuart, Gail W. (2006). Buku Saku Keperawatan Jiwa, edisi 5. Jakarta : EGC.

Subkhan, (2007). Hiruk Pikuk Wacana Pluralisme di Yogya. Yogyakarta : Kanisius.

Sugiyono. (2008). Statistik Untuk Penelitian. Bandung: Alfabeta

Suliswati dan Sundari. (2005). Konsep Dasar Keperawatan Kesehatan Jiwa. Jakarta: EGC.

Waite, (2003). http:// www. waite. adelaide. edu. 